\title{
ANALISIS PENGARUH PROSEDUR KREDIT DAN KUALITAS PELAYANAN TERHADAP KEPUTUSAN PENGAMBILAN KREDIT DI CV.SAHABAT SOLUTION
}

\author{
Irvan Situmorang ${ }^{1}$, Kusnarli ${ }^{2}$ \\ ${ }^{1}$ STIE Eka Prasetya, Medan,Indonesia \\ ${ }^{1}$ STIE Eka Prasetya, Medan,Indonesia \\ ${ }^{2}$ kusunaruli@yahoo.co.id
}

\begin{abstract}
This study aims to determine whether the Credit Procedure has an influence on Credit Taking Decisions on CV. Sahabat Solution, knowing Service Quality has an influence on Credit Taking Decisions on CV. Sahabat Solution and find out whether Credit Procedure and Service Quality have an influence on Credit Taking Decisions on CV. Sahabat Solution. The research methodology used is descriptive quantitative method. The type of data used in this study is quantitative data, namely data obtained in the form of numbers or numerals. Data sources are primary and secondary data. Primary data is obtained from the results of distributing questionnaires to consumers who buy credit at CV. Sahabat Solution, secondary data is obtained from data data and literature which are related to the issues discussed. The population in this study is the number of consumers who buy credit at CV. Sahabat Solution is 801 people. By using the Slovin formula, the number of samples obtained are 267 people. Data were analyzed using the method of multiple linear regression analysis. The results of the research analysis show that the credit procedure has a significant and positive influence on credit. The results of the analysis show that service quality has a significant and positive influence on credit.
\end{abstract}

Keywords : Credit Procedure, Service Quality, and Credit Taking Decisions.

\begin{abstract}
ABSTRAK
Penelitian ini bertujuan untuk mengetahui apakah Prosedur Kredit memiliki pengaruh terhadap Keputusan Pengambilan Kredit pada CV. Sahabat Solution, mengetahui Kualitas Layanan memiliki pengaruh pada Keputusan Pengambilan Kredit di CV. Sahabat Solution dan cari tahu apakah Prosedur Kredit dan Kualitas Layanan memiliki pengaruh terhadap Keputusan Pengambilan Kredit di CV. Solusi Sahabat. Metodologi penelitian yang digunakan adalah metode deskriptif kuantitatif. Jenis data yang digunakan dalam penelitian ini adalah data kuantitatif, yaitu data yang diperoleh dalam bentuk angka atau angka. Sumber data adalah data primer dan sekunder.
\end{abstract}


Data primer diperoleh dari hasil penyebaran kuesioner kepada konsumen yang membeli kredit di CV. Solusi Sahabat, data sekunder diperoleh dari data data dan literatur yang terkait dengan masalah yang dibahas. Populasi dalam penelitian ini adalah jumlah konsumen yang membeli kredit di CV. Solusi Sahabat adalah 801 orang. Dengan menggunakan rumus Slovin, jumlah sampel yang diperoleh adalah 267 orang. Data dianalisis menggunakan metode analisis regresi linier berganda. Hasil analisis penelitian menunjukkan bahwa prosedur kredit memiliki pengaruh yang signifikan dan positif terhadap pengambilan keputusan kredit. Hasil analisis menunjukkan bahwa kualitas layanan memiliki pengaruh yang signifikan dan positif terhadap pengambilan keputusan kredit.

Kata Kunci : Prosedur Kredit, Kualitas Layanan, dan Keputusan Pengambilan Kredit.

\section{PENDAHULUAN}

Diera kehidupan yang serba instan ini membuat setiap masyarakat ingin mendapatkan segala sesuatu barang dan jasa secara instan dan tanpa ribet. Begitu juga dengan sifat komsutif dari masyarakat akan barang-barang perabot dan elektronik yang mereka inginkan secara instan tanpa ribet dan tanpa memiliki uang tunai yang cukup untuk memiliki barang tersebut. Untuk memenuhi kebutuhan akan sifat yang konsumtif masyarakat yang dimana tidak memiliki dana untuk melakukan pembelian secara normal yaitu secara uang kontan, maka disinilah perusahaan pembiayaan kredit sangat penting dan bermanfaat untuk masyarakat. Kredit merupakan fasilitas yang diberikan perusahaan kredit yang memungkinkan para konsumennya dapat membeli produk yang diinginkan tanpa harus mengeluarkan uang tunai sendiri dan dapat membayar kembali sesuai dengan jangka waktu dan bunga yang telah disepakati bersama terdahulunya. Dikarenakan setiap perusahaan memberikan prosedurprosedur pengajuan kredit yang berbeda-beda, maka prosedur kredit menjadi salah satu faktor konsumen dalam menentukan perusahaan kredit mana yang akan mereka gunakan untuk sebagai perusahaan pembiayaan kredit mereka. Melihat dari sisi tersebut, masing-masing perusahaan pembiayaan kredit memberi atau menawarkan system prosedur-prosedur kredit yang berbeda-beda untuk menarik minat dari para konsumen.

Pada CV. Sahabat Solution sendiri masih menggunakan prosedur yang dikategorikan lambat dibandingkan dengan para pesaingnya. Dimana dalam CV. Sahabat Solution mewajibkan surveyor dari CV. Sahabat Solution untuk melakukan tinjauan kerumah konsumen dan melakukan penglihatan akan situasi dan kondisi dari lingkungan dan rumah konsumen Setelah data diterima dan dibuat surveyor CV. Sahabat Solution, maka data tersebut akan dimasukkan dan diajukan kepada bagian filter dari CV. Sahabat Solution di kantor keesokan harinya. Setelah melakukan penyaringan data, maka akan hasil yang di keluarkan CV. Sahabat Solution terhadap pengajuan kredit konsumen baik itu diterima ataupun ditolak. Dari sisi ini saja kita bisa melihat bahwa CV. Sahabat Solution membutuhkan minimal waktu satu hari atau 
lebih untuk memproses satu pengajuan kredit dari konsumen. Hal ini jauh lebih lambat dibandingkan pesaing mereka yang hanya membutuhkan waktu hanya kurang lebih sekitar 30 (tiga puluh) menit saja, hasil pengajuan konsumen sudah bisa didapat.

Bagi perusahaan yang tidak menjalankan prosedur kredit cepat tadi lebih condong terhadap kualitas pelayanan yang mereka miliki untuk para konsumennya. Karena bagi perusahaan yang bergerak di bidang jasa, kualitas pelayanan merupakan salah satu faktor yang membuat konsumen nyaman dan menjadi royal kepada perusahaan tersebut. Dimana pelayanan yang diberikan mampu memberikan kepuasaan yang dibutuhkan oleh setiap konsumen yang berbeda, baik dari karyawan perusahaan tersebut sendiri maupun dari fasilitas yang akan diberikan kepada konsumen..

Dalam kantor CV. Sahabat Solution, kualitas pelayanan adalah salah satu hal tuntutan yang sangat dipentingkan. Tetapi dikarenakan daya ingat, emosional, dan sikap tingkah laku setiap karyawan dari CV. Sahabat Solution itu berbeda, maka kualitas pelayanan menjadi salah satu hambatan tentunya.. Dimana kualitas pelayanan yang diberikan setiap karyawan CV. Sahabat Solution berbeda-beda maka membuat perasaan kepuasan kepada konsumen CV. Sahabat Solution sendiri menjadi berbeda-beda. Dimana dengan contoh karyawan kantor CV. Sahabat Solution yang terkadang lupa untuk menelepon konsumen mereka untuk mengingatkan jatuh tempo konsumen yang membuat konsumen menjadi telat untuk membayar cicilan yang dimana dalam keterlambatan yang akan dikenakan denda kepada konsumen, ataupun dengan sifat karyawan yang terlalu kasar dalam bertugas untuk melakukan penagihan piutang yang membuat perasaan tidak nyaman yang dirasakan oleh konsumen. Berdasarkan uraian latar belakang dan fenomena yang telah diuraikan di atas, maka tujuan penelitian ini adalah 1).Untuk mengetahui pengaruh Prosedur Kredit terhadap Keputusan Pegambilan Kredit Di CV. Sahabat Solution. 2).Untuk mengetahui pengaruh Kualitas Pelaynan terhadap Keputusan Pegambilan Kredit Di CV. Sahabat Solution 3). Untuk mengetahui pengaruh Prosedur Kredit dan Kualitas Pelayanan terhadap Keputusan Pegambilan Kredit Di CV. Sahabat Solution.

\section{KAJIAN LITERATUR}

\subsection{Keputusan Pengambilan Kredit}

Kotler dan Amstrong (2009:99) mendefinisikan keputusan pengambilan kredit ialah "suatu tindakan dari dua atau lebih pilihan alternatif. Dengan kata lain, orang yang akan mengambil keputusan harus mempunyai satu pilihan dari beberapa alternatif yang tersedia". Dan menurut Kotler dan Amstrong (2009:99) ada 5 indikator Keputusan Pengambilan Kredit, antara lain : 1) Persepsi Melihat Kinerja Karyawan, 2) Kepuasan akan kredit yang di tawarkan, 3) Penyediaan informasi pada saat diminta, 4) Kepercayaan terhadap kelompok referensi, 5) Pertimbangan Pelayanan.

\subsection{Prosedur Kredit}

Menurut Mudrajad Kuncoro (2002:245) mengungkapkan bahwa "Prosedur Kredit merupakan upaya lembaga keuangan untuk mengurangi resiko dari pemberian kredit, yang di mulai dengan tahap penyusunan perencanaan kredit, proses pemberian kredit, yang dimulai dengan tahap penyusunan perencanaan kredit, proses pemberian keputusan kredit, penyusunan 
pemberian kredit, dokumentasi, administrasi kredit persetujuan, pencairan serta pengawasan dan pembinaan kredit. Dan menurut Murdrajad Kuncoro(2002:245) ada 4 indikator Prosedur Kredit, antara lain : 1)Realisasi Kredit, 2)Kemudahan Prosedur, 3)Kecepatan Pelaksanaan, 4) Persyaratan.

\subsection{Kualitas Pelayanan}

Menurut Tjiptono dan Chandra (2012:70) mendefinisikan kualitas pelayanan adalah "ukuran seberapa bagus tingkat layanan yang diberikan perusahaan mampu sesuai dengan ekspetasi pelanggan”. Dan menurut Tjiptono ada 4 indikator untuk Kualitas Pelayanan, antara lain: 1) Realibilitas, 2) Responsivitas, 3) Jaminan, 4) Bukti Fisik.

Berikut pengujian hipotesis penelitiannya:

H1. Terdapat pengaruh positif dan signifikan Prosedur Kredit terhadap Keputusan Pengambilan Kredit.

H2. Terdapat pengaruh positif dan signifikan Kualitas Pelayanan terhadap Keputusan Pengambilan Kredit.

H3. Terdapat pengaruh positif dan signifikan Prosedur Kredit dan Kualitas Pelaynan terhadap Keputusan Pengambilan Kredit

Kerangka teoritis dalam penelitian ini akan menjelaskan hubungan antara masingmasing variable dapat dilihat pada Gambar 1 .

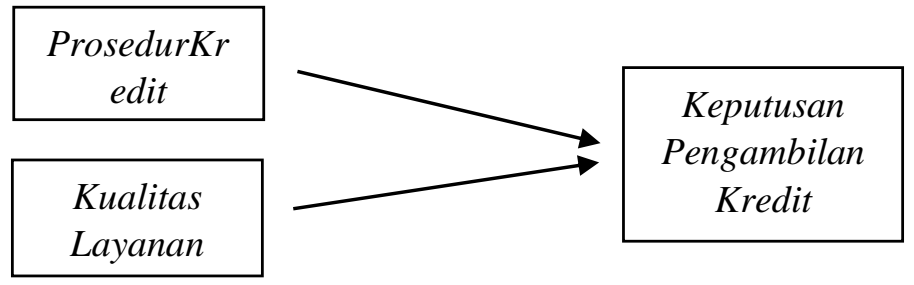

Gambar 1. Kerangka Penelitian

\section{METODE PENELITIAN}

Lokasi penelitian ini adalah kantor CV. Sahabat Solution di jalan Kelambir V No 52, Medan. Dalam penelitian ini, populasi yang digunakan adalah konsumen pada CV. Sahabat Solution sebanyak 801 responden. berdasarkan perhitungan dengan rumus Slovin diperoleh sampel dalam penelitian ini sebanyak 267 konsumen. Menurut Sugiyono (2017:121), teknik pengumpulan data dilakukan dengan cara angket, wawancara, dan dokumentasi Teknik pengumpulan data yang digunakan peneliti adalah dengan metode angket dengan cara mengedarkan daftar pertanyaan yang harus diisi oleh responden yang akan dijadikan sampel dari populasi.

Dalam penelitian ini, teknik analisis regresi linear berkaitan dengan studi mengenai ketergantungan variabel dependen dengan variable independen, dengan tujuan untuk mengestimasi dan memprediksi rata-rata populasi atau nilai rata-rata variable dependen berdasarkan nilai independen yang diketahui. Anilisis liner berganda digunakan untuk 
mengetahui pengaruh Prosedur Kredit(X1)dan Kualitas Pelayanan(X2) terhadap Keputusan Pengambilan Kredit(X3). Perhitungan dapat dirumuskan dengan formula sebagai berikut ini.

$$
\mathrm{Y}=\alpha+\beta 1 \mathrm{X} 1+\beta 2 \mathrm{X} 2+\mathrm{e}
$$

Keterangan :

$\mathrm{Y}=$ Keputusan Pengambilan Kredit

$\mathrm{X} 1=$ Prosedur Kredit

$\mathrm{X} 2=$ Kualitas Pelayanan

$\alpha=$ konstanta

$\beta 1=$ koefisien untuk variable Prosedur Kredit.

$\beta 2=$ koefisien untuk variabel Kualitas Pelayanan

\section{HASIL DAN PEMBAHASAN}

Pengujian validitas dilakukan dengan mengkorelasikan skor setiap item pernyataan dengan total skor, dimana korelasi yang digunakan adalah person product moment correlation dengan ketentuan bahwa item kuesioner tersebut dinyatakan valid atau sah jika koefisien korelasi (r) bernilai positif dan lebih besar dari $=0,3$. Penggunaan item-item sebagai indikatorindikator dari data variable penelitian mensyaratkan adanya suatu pengujian konsistensi melalui uji reliabilitas, sehingga data yang digunakan tersebut benar-benar dapat dipercaya atau memenuhi aspek kehandalan untuk dianalisis lebih lanjut. Hasil uji Validitas dan Reliabilitas akan disajikan pada tabel berikut:

Tabel 1. Uji Validitasi

\begin{tabular}{llll}
\hline No & Pernyataan & Variabel & Rhitung \\
\hline 01 & PK-1 & Prosedur Kredit & 0,798 \\
02 & PK-2 & Prosedur Kredit & 0,756 \\
03 & PK-3 & Prosedur Kredit & 0,817 \\
04 & PK-4 & Prosedur Kredit & 0,554 \\
\hline 01 & KP-1 & Kualitas Pelayanan & 0,816 \\
02 & KP-2 & Kualitas Pelayanan & 0,612 \\
03 & KP-3 & Kualitas Pelayanan & 0,721 \\
04 & KP-4 & Kualitas Pelayanan & 0,712 \\
\hline
\end{tabular}

Dari hasil tabel 1 diperoleh nilai $\mathrm{r}$ hitung dari masing-masing item pernyataan untuk setiap variable diperoleh di ata 0,361 sehingga dapat dikatakan pernyataan yang digunakan dalam variable penelitian dikatakan validitas. 


\subsection{Uji Normalitas}

Uji normalitas bertujuan untuk menguji apakah dalam model regresi variabel pengganggu atau residual memiliki distribusi normal. Ada tiga cara untuk mendeteksi apakah residual berdistribusi normal atau tidak, yaitu dengan analisis grafik, uji statistik dan Uji Kolmogrov-Smirnov. Ketiga cara ini digunakan untuk mengetahui apakah sebuah model regresi berdistribusi normal atau tidak.

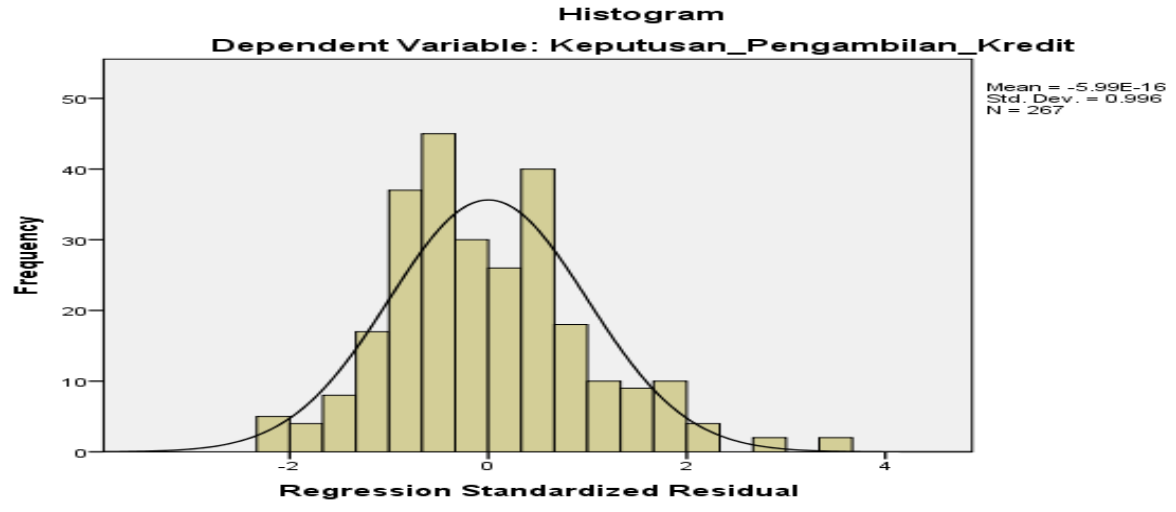

Gambar 2. Grafik Histogram

Dari Gambar 2 dapat dilihat bahwa data menyebar garis diagonal dan mengikuti arah garis diagonal atau grafik histogramnya menunjukkan pola distribusi normal, maka model regresi dianggap memenuhi asumsi normalitas

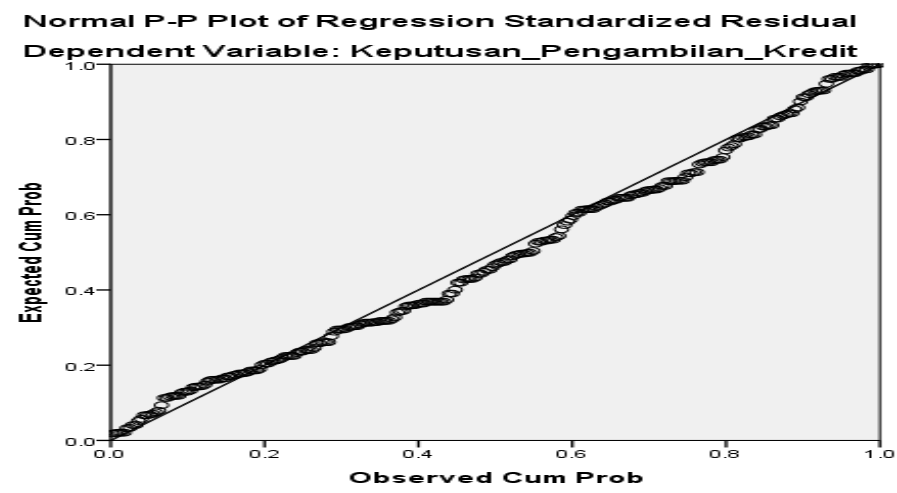

Gambar 3. Normal P-P Plot

Dari Gambar 3 menunjukkan bahwa data (titik) menyebar di sekitar garis normal dan mengikuti arah garis diagonal atau grafik Normal Probabilty Plot menunjukkan pola distribusi normal. Berdasarkan tabel 3 di atas, maka dapat diketahui nilai signifikan lebih besar dari 0.05, yaitu sebesar 0,197 Hasil pengujian ini menunjukkan bahwa data dalam model regresi ini berdistribusi secara normal. 


\subsection{Hasil Analisis Regresi Linear Berganda}

\begin{tabular}{|c|c|c|c|c|c|c|}
\hline \multicolumn{7}{|c|}{ Coefficients $^{a}$} \\
\hline \multirow{2}{*}{\multicolumn{2}{|c|}{ Model }} & \multicolumn{2}{|c|}{$\begin{array}{c}\text { Unstandardized } \\
\text { Coefficients }\end{array}$} & \multirow{2}{*}{$\begin{array}{c}\text { Standardized } \\
\text { Coefficients } \\
\text { Beta } \\
\end{array}$} & \multirow[t]{2}{*}{$\mathrm{t}$} & \multirow[t]{2}{*}{ Sig. } \\
\hline & & $\mathrm{B}$ & Std. Error & & & \\
\hline \multirow{3}{*}{1} & (Constant) & 4.487 & 1.140 & & 3.935 & .000 \\
\hline & Prosedur_Kredit & .320 & .059 & .283 & 5.403 & .000 \\
\hline & Kualitas_Pelayanan & .516 & .064 & .424 & 8.098 & .000 \\
\hline
\end{tabular}

a. Dependent Variable:Keputusan_Pengambilan_Kredit

Gambar 4. Standardized Coefficients

Dari tabel 5, uji regresi linear berganda diperoleh persamaan regresinya adalah: Keputusan Pengambilan Kredit $=4.487+0.320$ Prosedur Kredit +0.516 Kualitas Pelayanan . Penjelasan persamaan sebagai berikut:

1. Konstanta sebesar 4.487 menyatakan bahwa jika variable Prosedur Kredit dan Kualitas Pelayanan dianggap konstan, maka nilai keputusan pengambilan kredit sebesar 4.487.

2. Variabel Prosedur Kredit mempunyai nilai koefisien regresi sebesar 0.320 dan bertanda positif yang artinya setiap kenaikan nilai Prosedur Kredit sebesar satu mengakibatkan kenaikan Keputusan Pengambilan Kredit sebsar 0.320.

3. Variabel Kualitas Pelayanan mempunyai nilai koefisien regresi sebesar 0.516 dan bertanda positif yang artinya setiap kenaikan nilai Kualitas Pelayanan sebesar satu mengakibatkan kenaikkan Keputusan Pengambilan Kredit sebesar 0.516.

\subsection{Hasil Pengujian Hipotesis}

\section{Uji t (Uji Parsial)}

Uji t digunakan untuk melihat secara parsial apakah ada pengaruh yang signifikan dari variabel bebas terhadap variabel terikat. Bentuk pengujiannya adalah sebagai berikut:

\begin{tabular}{|c|c|c|c|c|c|c|}
\hline \multicolumn{7}{|c|}{ Coefficients ${ }^{a}$} \\
\hline \multirow{2}{*}{\multicolumn{2}{|c|}{ Model }} & \multicolumn{2}{|c|}{$\begin{array}{c}\text { Unstandardized } \\
\text { Coefficients }\end{array}$} & \multirow{2}{*}{$\begin{array}{c}\text { Standardized } \\
\text { Coefficients } \\
\text { Beta } \\
\end{array}$} & \multirow[t]{2}{*}{$t$} & \multirow[t]{2}{*}{ Sig. } \\
\hline & & $\mathrm{B}$ & Std. Error & & & \\
\hline \multirow{3}{*}{1} & (Constant) & 4.487 & 1.140 & & 3.935 & .000 \\
\hline & Prosedur_Kredit & .320 & .059 & .283 & 5.403 & .000 \\
\hline & Kualitas_Pelayanan & .516 & .064 & .424 & 8.098 & .000 \\
\hline
\end{tabular}

a. DependentVariable:Keputusan_Pengambilan_Kredit

Gambar 5. Uji t

Nilai $t_{\text {tabel }}$ untuk probabilitas 0,05 pada derajat bebas $(\mathrm{df})=264$ adalah sebesar 1,96899 . Uji ini dilakukan dengan membandingkan $t_{\text {hitung }}$ dengan $t_{\text {tabel }}$ dengan ketentuan sebagai berikut:

$\mathrm{H}_{0}$ diterima jika $-\mathrm{t}_{\text {tabel }} \leq \mathrm{t}_{\text {hitung }} \leq \mathrm{t}_{\text {tabel, }}$ sig $>0,05$ 
$\mathrm{H}_{0}$ diterima jika $-\mathrm{t}_{\text {tabel }} \leq \mathrm{t}_{\text {hitung }} \leq \mathrm{t}_{\text {tabel, }}$ sig $<0,05$

Dengan demikian hasil dari Uji t dapat dijelaskan sebagai berikut:

1. Hasil perhitungan uji $t$ secara parsial diperoleh nilai $t_{\text {hitung }}$ prosedur kredit sebesar 5,403 dengan nilai signifikan sebesar 0,000. Nilai $t_{\text {hitung }}>t_{\text {tabel }}$ atau 5,403>1,96899 maka $\mathrm{H}_{0}$ ditolak atau $\mathrm{H}_{1}$ diterima artinya secara parsial prosedur kredit berpengaruh positif signifikan terhadap keputusan pengambilan kredit pada CV. Sahabat Solution

2. Hasil perhitungan uji $\mathrm{t}$ secara parsial diperoleh nilai thitung kualitas pelayanan sebesar 8,098 dengan nilai signifikan sebesar 0,000. Nilai $t_{\text {hitung }}>t_{\text {tabel }}$ atau 8,098>1,96899 maka $\mathrm{H}_{0}$ ditolak atau $\mathrm{H}_{1}$ diterima artinya secara parsial kualitas pelayanan berpengaruh positif signifikan terhadap keputusan pengambilan kredit pada CV. Sahabat Solution.

\section{Uji F}

Uji F pada dasarnya menunjukkan apakah semua variabel bebas yang dimasukkan dalam model mempunyai pengaruh secara simultan terhadap variabel dependen. Uji $F$ digunakan untuk menguji pengaruh dimensi variabel bebas secara serempak terhadap variabel terikat.

Tabel 7. Uji F (Uji Simultan)

Uji F

ANOVA ${ }^{a}$

\begin{tabular}{|c|c|c|c|c|c|c|}
\hline \multicolumn{2}{|c|}{ Model } & Sum of Squares & df & Mean Square & $\mathrm{F}$ & Sig. \\
\hline \multirow{3}{*}{1} & Regression & 582.760 & 2 & 291.380 & 52.035 & $.000^{\circ}$ \\
\hline & Residual & 1478.318 & 264 & 5.600 & & \\
\hline & Total & 2061.079 & 266 & & & \\
\hline
\end{tabular}

a. DependentVariable:Keputusan_Pengambilan_Kredit

b. Predictors: (Constant), Kualitas_Pelayanan,Prosedur_Kredit

Hasil analisis regresi secara simultan (F test) variabel independen prosedur kredit dan kualitas pelayanan terhadap keputusan pengambilan kredit didapatkan $F_{\text {hitung }}$ sebesar 52,035 dan nilai $\mathrm{F}_{\text {tabel }}$ untuk df $1=($ jumlah variabel-1) $=3-1=2$ dan df $2=(\mathrm{n}-\mathrm{k}-1)=267-2-1$ (n adalah jumlah data dan $\mathrm{k}$ adalah jumlah variable independen $=264$ yaitu sebesar 3,03. Karena $F_{\text {hitung }}>F_{\text {tabel }}$ dan nilai signifikan sebesar $0,000<0,05$ maka prosedur kredit dan kualitas pelayanan secara simultan mempunyai pengaruh yang positif dan signifikan terhadap keputusan pengambilan kredit pada CV. Sahabat Solution.

\section{SIMPULAN}

Hasil penelitian ini menyatakan pengaruh Prosedur Kredit (X1) dan Kualitas Pelayanan (X2) terhadap Keputusan Pengambilan Kredit Di CV. Sahabat Solution (Y) ditunjukkan dari hasil analisis regresi linear berganda Keputusan Pengambilan Kredit $=4.487$ +0.320 Prosedur Kredit + 0.516 Kualitas Pelayanan. Hal ini memberikan arti bahwa varibel 
Prosedur Kredit dan Kualitas Pelayanan secara bersama-sama mempunyai pengaruh terhadap Keputusan Pengambilan Kredit Di CV. Sahabat Solution. Hasil Uji koefisien determinasi (R2) menunjukkan bahwa nilai $\mathrm{R}$ Square yang diperoleh adalah 0.283 , yang berarti $28,3 \%$ variabel Keputusan Pengambilan Kredit dipengaruhi oleh variabel Prosedur Kredit dan Kualitas Pelayanan, sedangkan sisanya sebesar $71,7 \%$ dipengaruhi oleh variabel-variabel lainnya yang tidak diteliti dalam penelitian ini.

\section{DAFTAR PUSTAKA}

Andrianto, Didin Fatihuddin dan Anang Firmansyah. 2019. Manajemen Bank. Jawa Timur : CV. Penerbit Qiara Media

Baridwan, Zaki. 1998. Sistem Akuntansi : Penyusunan dan Prosedur dan Metode. Yogyakarta : BPFE.

Fen, Y.S., dan Lian, K.M., 2005, Service Quality and Customer Satiffaction: Antecedents of Customer's Re-Patronage Intention, Sunway Academic Journal, 4:56-73.

Manajemen Perkreditan Bank Umum: Teori, Masalah Kebijakan dan Aplikasinya. Cetakan Kelima. Bandung : Alfabeta.

Ghozali, Imam. 2016. Aplikasi Analisis Multivariate Dengan Program SPSS. Semarang: Badan Penerbit Universitas Diponegoro.

Ikatan Bankir Indonesia. 2015. Bisnis Kredit Perbankan. Jakarta : PT. Gramedia Pustaka Utama.

Ismail. 2010. Manajemen Perbankan dari Teori Menuju Aplikasi. Jakarta : PT Kencana.

Jogiyanto. 2005. Analisis dan Desain Sitem Informasi. Yogtakarta : Penerbit Andi.

Kasmir, 2014. Bank dan Lembaga Keuangan Lainnya, Edisi Revisi 2014. Jakarta : PT Raja Grafindo Persada.

Kotler, Philip dkk. 1996. Manajemen Prespektif Asia. Terjemahan Dandy Tjiptono. Marketing. 1999. Jakarta : Erlangga.

Kotler, 2005. Faktor - Faktor Keputusan Nasabah, Jakarta.

Kotler, Philip. 2008. Principle Of Marketing 12th Edition. Prinsip - Prinsip Pemasaran (12th Ed). Ahli Bahasa : Sabran, Bob. Jakarta : Erlangga. 